\title{
ACP5 wt Allele
}

National Cancer Institute

\section{Source}

National Cancer Institute. ACP5 wt Allele. NCI Thesaurus. Code C99182.

Human ACP5 wild-type allele is located within 19p13.3-p13.2 and is approximately 4 kb in length. This allele, which encodes tartrate-resistant acid phosphatase type 5A protein, is involved in the modulation of dephosphorylation. Mutation of the gene is associated with spondyloenchondrodysplasia with immune dysregulation. Elevated expression of the gene is associated with Gaucher and Hodgkin diseases, and with hairy cell, B-cell, and Tcell leukemias. 